\title{
The Comparison of Sleep's Quantity and Quality Elite Volleyball Male Athletes at Various Level of Events
}

\author{
Erlin Nika Saputri ${ }^{1}$, Muhammad Labib Siena Ar Rasyid ${ }^{1}$, Machfud Irsyada ${ }^{1}$, Tutur Jatmiko ${ }^{1}$, \\ Kunjung Ashadi ${ }^{1}$ \\ \{erlin.17060474029@mhs.unesa.ac.id ${ }^{1}$, muhammad.17060474017@mhs.unesa.ac.id², \\ machfudirsyada@unesa.ac.id $\left.{ }^{3}\right\}$
}

Universitas Negeri Surabaya, Surabaya, Indonesia ${ }^{1}$

\begin{abstract}
The purpose of this study was to compare the quantity and quality of sleep for men athletes at the Club, Regional Training Center (Puslatda), and National Training Center (Pelatnas). The method uses descriptive quantitative. The target is six Puslatda's male volleyball athletes. The maximum age is 25 years and already participated in three conditions: Club, Puslatda, and Pelatnas. The instrument uses interview questions to determine sleep quantity and a questionnaire for sleep quality. The questionnaire has passed the validity test with a value (0.820) and reliability (0.976). The data analysis technique used mean, standard deviation, One Way Anova test on normally distributed data, and Kruskal Wallis test for not normally distributed data. The result showed the quantity and quality of sleep at the Club, Puslatda, and Pelatnas had a value (p>0.05). The conclusion showed no significant difference between the quantity and quality of sleep at the three levels.
\end{abstract}

Keywords: quantity, quality, sleep, athlete, physical recovery.

\section{Introduction}

In supporting sports performance, athletes need to be given in-depth training, namely training is carried out in a structured, scheduled, and planned manner in a training program and the needs in a good athlete's physical condition to support the athlete's achievement. Apart from being given intensive training, recovery is also needed to support maximum achievement [1]. However, if it is not supported by adequate energy and nutritional intake, optimal physical conditions will not be achieved [2].

However, recovery should not be neglected and should not be underestimated because recovery is a body condition in restoring human metabolism's function before doing activities to return to its prime and return to show good performance[1]. Because without a good recovery, it will take a long time to restore the body to its initial phase. If this happens, the athlete's body condition will not be ready when receiving new training material. It will be detrimental to the athlete if it is forced because the training will not be optimal [3].

Recovery is divided into two, namely physiological recovery and psychological recovery. Physiological recovery is the process of returning the body's condition to display optimally through the physical aspects[4]. In physiological recovery, there are several strategies used, such as compression clothing, hydrotherapy, sleep, massage, stretching, active recovery, and hydration [5]. 
Recovery has the goal of minimizing the risk of switching to a state of overexertion and reducing the athlete's risk of injury. One of the recovery strategies in overcoming this bad condition can be done by controlling sleep[6].

In some experts' opinion, sleep is believed to restore one's energy because sleeping can give the body time to recover and recover. It is healing of one's body systems to obtain awake the next day. What is interesting in the biological functioning system is sleep. Because no less than a third of life is spent sleeping, it all becomes normal when someone sleeps soundly, so in the morning, when awakened from sleep, the body feels refreshed and can carry out activities better than when someone lacks in rest [7].

Therefore, a person needs to be sufficient in his sleep to maintain a balanced body condition. However, of course, when practicing at a high level, he experiences the limitations and pressures of life. One of them is a lifestyle caused by physiological, psychological demands, and training or competition schedules [8]. Especially in volleyball, since volleyball is a team sport that requires much active movement. Starting from good physical and mental, movement skills complex, and good teamwork [9].

In sports, achieving the best performance fosters a sport and athlete [10]. The achievements have been made in volleyball at events national and international, namely the PON and SEA GAMES championships.

The East Java Puslatda (Regional Training Center) men's volleyball team achieved an achievement, namely the gold medal in the West Java XIX PON competition in 2016. This achievement is the fifth successive achievement since PON 2000. Then, the Pelatnas men's volleyball team (National Training Center) also won achievement by bringing a gold medal for Indonesia at the 2019 SEA GAMES competition in the Philippines.

To maintain these achievements, it needs adequate sleep for the human body, considering that sleep has a significant role in restoring its performance. The need for sleep is not only determined by the duration of sleep hours (sleep quantity) but also the depth of sleep (sleep quality) is required [11]. Sleep needs are differentiated by age, according to Samuels \& Alexander [12] in the Canadian Sport for Life recommendations for sports sleep at the LTAD (Long Term Athlete Development)for women aged 18 +/- and men $19+/-$ namely 8-10 hours/night plus 30 minutes of naps. Adequate sleep is needed because many impacts arise on physical health, mental, and mood, and one's immunity [13].

Therefore, a balance in regulating sleep quantity and sleep quality is essential and must be considered. Because of poor sleep quality, it will impact a person's physical and physiological functions so that it will all adversely affect health, and the activities carried out are hampered. As a result, someone who experiences sleep disturbances will experience several impacts such as disruption of the balance of the diet and disturbed body weight due to the release of body hormones so that hunger appears ultimately challenging to control. Then the body feels weak and is more susceptible to disease because of a compromised immune system. Besides, when experience sleep disturbances, it also affects psychologically. As a result, the mood becomes terrible, resulting in depression and decreased motivation, affecting athletes' performance [14].

Putra et al [15] explained that lack of sleep could result in an imbalance between hormone cycles and body metabolism, so the impact caused by irregularly maintaining this sleep pattern will be at risk of contracting heart disease, diabetes, stress, and depression. However, when a person implements a good and regular sleep pattern, it will also positively impact physical fitness; therefore, the following activities can be carried out optimally [16].

Suppose further analysis shows that these situations are interrelated and become a cycle because the physical activity carried out routinely and in a structured manner affects sleep quality. Good sleep quality can increase the ability to work physically well. Therefore, 
adequate sleep is needed because it affects athletes' performance and learning [14]. Many things can be done to achieve a healthy sleep pattern. First, time discipline is essential to give attention since sleep experts believe that a regular rhythm schedule of sleep positively contributes to healthy sleep. Then, do a routine exercise, pay attention to the bedroom condition used, and try not to eat before sleep [7].

However, field observations that occur show that some athletes do sleep less controlled and then continue to exercise routine. However, sleep behavior does not affect the athlete's performance, which can be proven by obtaining good performance. This issue, of course, contradicts the theories of recovery. Because with recovery a good, one of them can be done adequately in sleep.

Based on the previous research above, the gaps in this study are the majority of athletes with the criteria for the quantity and quality of sleep for male elite volleyball athletes at the national and international levels with conditions, namely when at the Club, Regional Training Center (Puslatda) experienced a lack of daily sleep recommendations. Moreover, the National Training Center (Pelatnas) has met daily sleep recommendations. Lack of alertness is at risk of experiencing a decline in performance while training and while participating in championship competitions. Ideally, athletes should maintain a quantity of sleep and quality sleep to maintain endurance and stay in shape and give their best performance during training and competition. However, there is not enough data to show this fact.

The problem is the limited literature on the research results shows that athletes' sleep patterns both of sleep quantity and sleep quality by analyzing the comparison of good sleep patterns at the three levels, namely when at the Club, Puslatda, and Pelatnas as a material for further discussion. Therefore this study was conducted as a follow-up study and to determine the comparison of these sleep patterns. This study's novelty lies in the distinctive aspects of male volleyball athletes' research subjects at the national and international levels with conditions, namely when they are at clubs, Puslatda, and Pelatnas, by comparing the quantity and quality of sleep as a material for further discussion.

\section{Method}

The method used in this research is a quantitative method that is presented descriptively. Through a descriptive approach, the goal is to analyze the data by describing the factual data obtained without concluding it in general [17]. This study explained the comparison of the quantity and quality of sleep of Puslatda men's volleyball athletes while at the Club, Puslatda and Pelatnas.

In this study, the intended target for research was the male volleyball athletes of East Java Province following the Puslatda towards the National Sports Week (PON) in 2021, which took place in Papua in October with six research subjects. With the criteria, athletes have participated in three conditions: when at the Club, Puslatda, and Pelatnas. With a maximum age of 25 years. Research subjects have filled in informed consent, namely willingness to be research subjects and are already willing to become research subjects.

The instruments used were interview questions to determine sleep quantity and questionnaires to determine sleep quality. The questionnaire has been approved and validated by two validator lecturers following their scientific fields and is declared worthy of being used as a research instrument. The questionnaire was adopted from the ASBQ questionnaire in the journal of Sleep Science in 2018 by Matthew W Driller, Cheri D Mah, and Shona L. Halson 
entitled "Development of the Athlete Behavior Questionnaire: A tool for Identifying Maladaptive Sleep" that has adjusted to various stages according to the needs. This questionnaire has been calculated and passed the validity and reliability test using IBM SPSS Statistics version 24 with a validity value of (0.820) and a reliability value of (0.976).

Data was collected through video calls which were carried out for one month from October to November 2020. Furthermore, the collected data were processed using IBM SPSS Statistics version 24 and Microsoft Excel version 2019. The data analysis techniques used are percentage, minimum, maximum, mean, standard deviation, normality test using Kolmogorof-Smirnov, Levene test for homogeneity test, difference test using one-way ANOVA on normally distributed data, and Kruskal Wallis for not normally distributed data.

The following description of the interval of values of athletes sleep quality ratings as follows [18]:

$$
\text { Scale }=\frac{\text { maximum value }- \text { minimum value of }}{\text { the number of class }}=\frac{13-1}{5}=2.4
$$

Then votes variables calculated based on the average ratings for each variable, then suspended at intervals, as follows:

Table 1. Sleep quality assessment scale

\begin{tabular}{cc}
\hline Interval Score & Category \\
\hline $1-3.4$ & Very Poor \\
$3.5-5.9$ & Less \\
$6.0-8.4$ & Enough \\
$8.4-10.9$ & Good \\
$11.0-13.0$ & Very Good \\
\hline
\end{tabular}

\section{Result and Discussion}

The research data results have been interviewed via video call with reference questions to determine the quantity of sleep and sleep quality. The following is a description of the respondents who have been identified.

Table 2. Description from six respondents

\begin{tabular}{lccc}
\hline & Min & Max & Mean \& SD \\
\hline Height $(\mathrm{cm})$ & 176 & 196 & $190.67 \pm 7.47$ \\
Weight $(\mathrm{kg})$ & 66 & 88 & $81.50 \pm 8.02$ \\
BMI $\left(\mathrm{kg} / \mathrm{m}^{2}\right)$ & 21.3 & 23.4 & $22.4 \pm 0.78$ \\
Age Club & 19 & 24 & $22 \pm 2.00$ \\
Age Puslatda & 20 & 25 & $22.67 \pm 2.16$ \\
Age Pelatnas & 19 & 24 & $21.67 \pm 2.16$ \\
\hline
\end{tabular}

In the description of Table 2, it can be seen that the average height value is $190.67 \mathrm{~cm}$. The average athlete's weight was $81.50 \mathrm{~kg}$. The mean value of the body mass index (BMI) of athletes is $22.4 \mathrm{~kg} / \mathrm{m}^{2}$, which means normal. For the description of age, athletes are divided 
into three. When they are outside the Puslatda and Pelatnas or (Clubs), Puslatda and Pelatnas with an average age are 22 years old, Puslatda is 22.67 years old. When they are at Pelatnas, they are 21.67 years old.

Table 3. Description from six quantity of sleep's respondents

\begin{tabular}{llccc}
\hline & & Min & Max & Mean \& SD \\
\hline \multirow{2}{*}{ Total sleep } & Club & 7 & 9 & $7.50 \pm 0.837$ \\
quantity & Puslatda & 6 & 9 & $7.67 \pm 1.033$ \\
& Pelatnas & 7 & 10 & $8.67 \pm 1.211$ \\
Quantity sleep & Club & 4 & 7 & $6.00 \pm 0.84$ \\
the night & Puslatda & 6 & 8 & $6.50 \pm 1.03$ \\
& Pelatnas & 6 & 8 & $6.83 \pm 1.21$ \\
\multirow{4}{*}{ Naps } & Club & 0 & 3 & $1.50 \pm 1.05$ \\
& Puslatda & 0 & 2 & $1.17 \pm 0.84$ \\
& Platnas & 1 & 3 & $1.83 \pm 0.75$ \\
\hline
\end{tabular}

*Calculate in Hours

The average age at the Club is 22 years old with an average total sleep quantity in one day of 7.50 hours, mean -The average night sleep is 6.00 hours, the average naps are 1.50 hours, with the information on the quantity in the recommendation that the number of hours of sleep daily is still not fulfilled and the quantity is still more when in Pelatnas and Puslatda, then on the average age in the Puslatda category, namely 22.67 years old with an average total sleep quantity in one day of 7.67 hours, an average night sleep of 6.50 hours, an average nap of 1.17 hours, with information on this quantity in the recommendation of the number of hours of sleep daily is still not meme nuhi and less than Pelatnas and more total sleep quantity than Clubs, at an average age in the Pelatnas category aged 21.67 years with an average total sleep quantity in one day 8.67 hours, an average night sleep of 6.83 hours, average nap 1.87 hours, with the information on the quantity in the recommended daily number of sleep hours has been fulfilled and the quantity is longer than the Puslatda and Club categories.

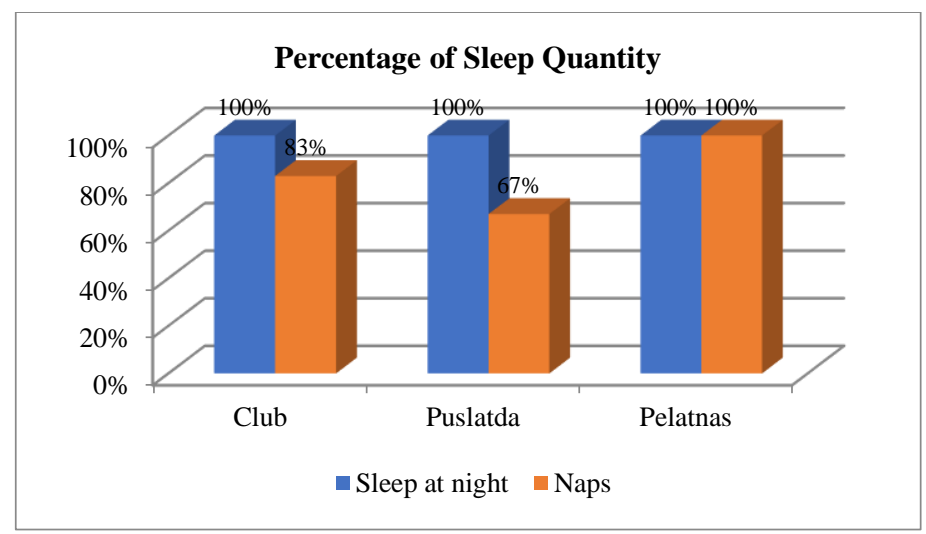

Fig. 1. Percentage of sleep quantity

Figure 1 shows the percentage of sleep quantity athletes doing nighttime naps and naps. The percentage results of the average quantity of sleep at night in volleyball athletes while at the Puslatda, Pelatnas, Clubs (6 athletes) are 100\%. Meanwhile, the results of the percentage 
of the average quantity of daytime naps in volleyball athletes while at the Puslatda, Pelatnas, Clubs were (1 athlete) $17 \%$.

These results illustrate that the higher the athlete's training level, the greater the impetus that will make the athlete train more while maintaining the quantity and quality of sleep to appear to give the best results when competing by maintaining the quantity of sleep both at night and during the day.

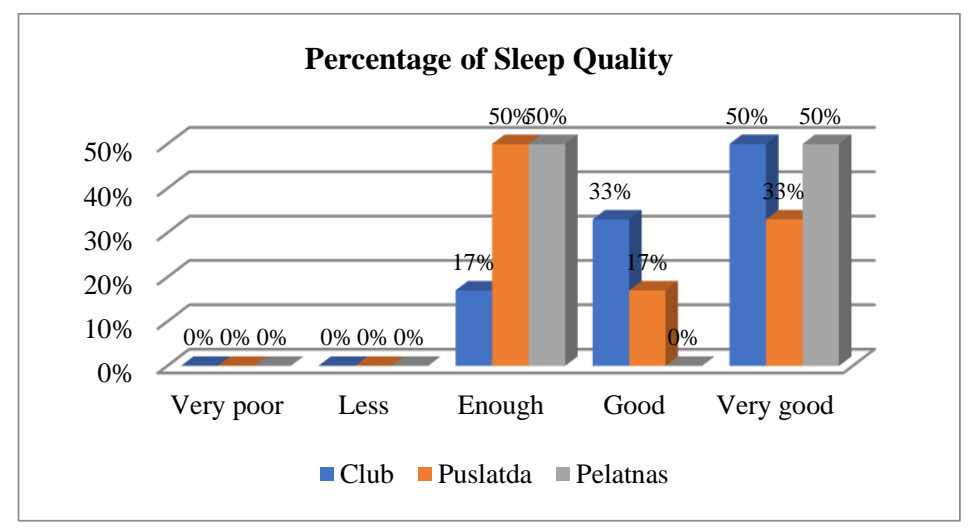

Fig. 2. Percentage of sleep quality

The percentage of athletes' sleep quality results in the volleyball sport at Puslatda, in the graphic image with a percentage label of $0 \%$, which means no athletes whose sleep quality is Very Poor and Poor. The enough category is the highest in Puslatda and Pelatnas with 50\%. The good category is mainly at the Club with 33\%, and the rest is Very Good category is mostly when at Pelatnas and Clubs with $50 \%$. The average presentation of the best sleep quality in the Club is $17 \%$ adequate, $33 \%$ is good, and the rest $50 \%$ is excellent.

The data that has been collected from the distributed sleep quality questionnaire is tabulated to be a data analysis tool. The tabulation results are processed to produce statistical descriptions of the research variables.

Table 4. Description from six quality of sleep's respondents

\begin{tabular}{lcccc}
\hline & Min & Max & Mean \& SD & Description \\
\hline Club & 7 & 13 & $10.33 \pm 2.160$ & Good \\
Puslatda & 7 & 13 & $9.33 \pm 2.422$ & Good \\
Pelatnas & 8 & 11 & $9.50 \pm 1.643$ & Good \\
\hline \multicolumn{5}{r}{ *Calculate in Hours }
\end{tabular}

Table 4 shows that athletes' sleep quality when at the Club is known that the average sleep quality as many as 10.33 points. Puslatda has an average sleep quality of 9.33 points, Pelatnas is known to have an average sleep quality of 9.50 points, which means that overall is in a Good sleep quality condition.

To find out the difference between the quantity and quality of sleep at the Puslatda, Pelatnas, and outside the Puslatda and Pelatnas or (Clubs) using One Way Anova analysis normality test using Kolmogorov Smirnov, which can be presented in tables 2 and 4. 
Table 5. Normality test

\begin{tabular}{|c|c|c|}
\hline \multicolumn{3}{|c|}{ One-Sample Kolmogorov-Smirnov Test } \\
\hline Variable & Asymp. Sig. & Information \\
\hline Total sleep quantity & $.050^{\mathrm{c}}$ & Normal \\
\hline Night sleep quantity & $.002^{\mathrm{c}}$ & Abnormal \\
\hline Quantity naps & $.002^{\mathrm{c}}$ & Abnormal \\
\hline Sleep quality & $.080^{\mathrm{c}}$ & Normal \\
\hline
\end{tabular}

Based on table 5, it is known that the Kolmogorov-Smirnov significance value Sig. of the quantity of sleep at night (0.002) and quantity of naps (0.002) where each value is less than 0.05 . The normality test on these two variables is not normally distributed so that the search for differences no longer uses the Anova test but uses the Kruskal Wallis method. The nonparametric statistics described in Table 6 are different from the variable total sleep quantity (0.50) and sleep quality (0.80). Each value is more significant than 0.05 , which means that the normality test uses a normally distributed Kolmogorov-Smirnov. Thus the requirements for the normality of the test model are met. The next step is to analyze the difference between total sleep quantity and sleep quality at the Puslatda, Pelatnas, and outside Puslatda and Pelatnas (or Clubs) in Table 7 using the group similarity test.

Table 6. Kruskal Wallis

\begin{tabular}{lccc}
\hline \multicolumn{4}{c}{ Test Statistics Test ${ }^{\mathbf{a}, \mathbf{b}}$} \\
\hline Night sleep quantity & Sig. & .359 & Not Significant \\
Quantity of naps & Sig. & .534 & Not Significant \\
\hline
\end{tabular}

Based on the Kruskal Wallis test results, which were carried out because the variable data was not normally distributed, the Sig value was obtained. On the quantity of sleep at night (0.359) and quantity of naps (0.534), each value is greater than 0.05 , which means no significant difference in the two variables.

Table 7. Homogeneity

\begin{tabular}{lcccc}
\hline \multicolumn{5}{c}{ Test of Homogeneity of Variances } \\
\hline \multirow{3}{*}{ Quantity sleep total } & df1 & df2 & Sig. & Description \\
Sleep quality & 2 & 15 & .526 & Homogeneous \\
\hline
\end{tabular}

The homogeneity test aims to test whether these variables have the same variance [19]. Based on the results of the Sig. The total sleep quantity is 0.526 , and the sleep quality is 0.624 in Table 7, which shows that ( $p>0.05$ ) where the problem formulation cannot be rejected which states the same variance, which means that the ANOVA assumption is fulfilled. According to Ghozali [20], this data is proven to be homogeneous. If data is not homogeneous in a group/category in sample size, it is not fatal to carry out the ANOVA test.

Table 8. One way ANOVA test

\begin{tabular}{lccc}
\multicolumn{4}{c}{ Table 8. One way ANOVA test } \\
\hline \multicolumn{3}{c}{ ANOVA } \\
\hline \\
Quantity total of beds & 2.216 & Sig. & Description \\
sleep Quality & .390 & .683 & Not Significant \\
\hline
\end{tabular}


In Table 8 is known Sig. at 0.143 sleep quantity and 0.683 sleep quality where ( $p>0.05$ ) which means that from the three categories Puslatda, Pelatnas, and outside Puslatda and Pelatnas (or Clubs), there is no significant difference.

Table 9. Post Hoc Test

\begin{tabular}{lllll}
\hline \multicolumn{4}{c}{ Multiple Comparisons } \\
\hline Tukey HSD & \multicolumn{1}{c}{ Category } & Sig. & \multicolumn{1}{c}{ Discription } \\
Total sleep quantity & Club & Puslatda & .958 & Not significant \\
& & Pelatnas & .160 & Not significant \\
& Puslatda & Pelatnas & .249 & Not significant \\
& & Club & .958 & Not significant \\
& Pelatnas & Puslatda & .249 & Not significant \\
& \multirow{4}{*}{ Club } & Club & .160 & Not significant \\
& \multirow{4}{*}{ Puslatda } & Puslatda & .694 & Not significant \\
& & Pelatnas & .774 & Not significant \\
& Pelatnas & Pelatnas & .990 & Not significant \\
& & Club & .694 & Not significant \\
& & Puslatda & .990 & Not significant \\
& & Club & .774 & Not significant \\
\hline
\end{tabular}

The Post Hoc Test Result in Table 9 shows the total quantity of sleep in a day; there is a category Club with Puslatda sig. 0.958>0.05. Clubs with National Pelatnas have known sig values. 0.160>0.05. In the category of Puslatda and Pelatnas, it is known that the sig value. 0.249> 0.05. Puslatda with the Club is known to have the Sig. 0.958>0.05. In the category of National Training Center with Puslatda, it is known that the sig value. 0.249>0.05. Pelatnas with the Club is known to be of Sig. 0.160>0.05. All the values described above mean no significant difference in the quantity of sleep in that category.

The Post Hoc Test results in Table 9 show that the quality of sleep in the Club category with Puslatda is known to be the sig value. 0.694>0.05. Clubs with National Pelatnas have known sig values. 0.774>0.05. At the Puslatda and Pelatnas, it is known that the sig value. 0.990> 0.05. Puslatda with the Club is known to have the Sig. 0.694>0.05. In the category of National Training Center with Puslatda, it is known that the sig value. 0.990>0.05. Pelatnas with the Club is known to be of Sig. 0.774>0.05. The values described above show that there is no significant difference in sleep quality in that category.

Success in sport is supported by optimal preparation and adequate recovery between training and competition [21]. Many strategies can be done in restoring the body, including sleeping [5].

Sleep is one of the strategies used as recovery to improve the condition of athletes to return to their optimal performance [22]. Sleep must be maintained because sleep is not just resting but when it is done properly and properly can provide positive benefits after running it [14]. Because it has been recognized that sleep has a significant influence on the role of performance and recovery of trained athletes [21].

It should be noted that during the sleep process the lowest phase cycle occurs for the activities metabolic body such as low blood flow to the brain, decreased heart rate, slows down of breathing, and when sleeping in the endocrine system the body increases the secretion of growth hormone through the pituitary gland which can restore physiologically [8]. Then 
besides that during the sleep process, the muscles are in a state not tense, so the muscles can recover and when they wake up they are in prime condition [23].

Several specific factors in sports influence the changes in the sleep conditions of elite athletes, such as the high training load being carried out, the type of exercise, the seasonal phase, the duration of training or competition, jet lag, and the environment (such as sleeping environment and use of transmitter media), also the methodology on sleep [8].

Judging from several factors that affect athletes' sleep condition, it is indispensable to control the human body's need for adequate sleep. This need is not only determined by the sleep time duration (sleep quantity) but also the need for the depth of sleep (sleep quality) [24]. For this reason, it is necessary to have adequate sleep because it has an impact on the physical health of athletes, mental, mood, and athletes' immunity [13].

Sleep quantity is the number of hours of sleep a person needs typically to sleep [25]. According to Samuels \& Alexander [12] in the Canadian Sport for Life, athlete sleep recommendations at the LTAD (Long Term Athlete Development) for women aged $18+/$ - and men $19+/-$, namely 8-10 hours/night plus 30 minutes of nap.

The results of research conducted by Milewski et al [26] show that athletes who sleep less than 8 hours are more likely to experience a risk of injury than athletes who sleep more than 8 hours. Previous studies also found that there was a significant relationship between lack of sleep and increased health complaints, increased stress, and decreased mood confusion. So, the resulting lack of sleep can lead to increased health problems, increased stress, decreased mood, especially in confusion [27].

This insufficient number of hours of sleep occurs because the training schedule in each category of Puslatda, Pelatnas, and Club has a different portion. The higher the competition level, the tighter and more strenuous the training schedule must be done so that athletes' sleep routine will change. Research conducted by Roberts et al [28] shows that athletes do not reach sleep recommendations during training and competition because the competition night disturbs sleep than the previous nights. Athletes' sleep disturbance is caused by training in the morning, increased training load, and departure during the trip, jet lag, and altitude.

Likewise, taking a nap during the day is thought to be an activity to improve body health but also has a bad influence on the risk of cardio-metabolic disease and can even cause death when it is not properly regulated. There is growing evidence that trials using sleep during the day can affect both a person's psychological and emotional regulation. But also on the contrary, if sleeping during the day is carried out for a long time in the afternoon, it can interfere with sleep at night and will have a bad risk to the metabolism body's [29].

For that, the quantity of sleep must be maintained properly. Awakening in the quantity of sleep can be done by maintaining nutritional intake and sleep volume because it is easy to understand the incidence of injury in athletes [30]. However, each athlete has certain strategies to regulate the exact portion of his sleep, which is not necessarily the same as other athletes. Where every athlete has a good physical condition, but strategies to regulate sleep patterns that result in different sleep quantities, but each athlete can still ensure their respective conditions are in the best condition.

In addition to the sleep time factor (sleep quantity), sleep depth (sleep quality) must also be considered. Because good sleep quality will create a positive mood or enthusiasm for athletes either when doing rigorous training for competition or when competition, which is supported by research conducted by Andrade et al [31] when analyzing the correlation between sleep quality, mood, and the results of the games in elite athletes participating in Brazilian volleyball competitions show that athletes who sleep well, with winning situations experience low levels of tension. Furthermore, the mood is related to success in a competition. 
Then when getting good quality sleep will have a good impact on increasing physical endurance so that in carrying out an activity on the body no longer experiences overtraining during training or competition so it can avoid muscle cramps or tension [32]. In other studies, it is also stated that there is a positive and significant relationship between sleep quality and concentration levels. So, good sleep quality can have a positive impact on concentration level [33].

However, when athletes have poor sleep quality it will also harm their performance. It can be caused by intrinsic and extrinsic factors. Where the intrinsic factors that occur are influenced by stress and pressure from someone such as family, coaches, and social life. Meanwhile, extrinsic factors that can affect sleep quality include environment, caffeine consumption, alcohol, level of exercise, snoring sound of sleeping partners, and room temperature of the bed [14]. These can all cause poor sleep quality. Of course, poor sleep quality will have an impact on someone who experiences it, such as disruption of diet balance and disturbed body weight due to the release of body hormones so that hunger appears, eventually, it is difficult to control. Then the body feels weak and is more susceptible to disease because of a compromised immune system. Besides, when you experience sleep disturbances it also affects the psychological, as result, the mood becomes bad so that you will feel depression and decreased motivation which will affect the performance of athletes [14].

With the study results, it was found that the quantity of sleep was not following the recommendations but still had good sleep quality so that elite athletes could wake up from sleep in a fit condition and good physical and psychological qualities. Some of the athletes' questions explained that the quality of sleep obtained was due to positive psychological thoughts to continue developing and providing the best for themselves, the team, and their families. Psychological factors such as a good mood, good environment, and a positive spirit can give the best performance for doing activities such as training or competing.

Li et al [34] supported athletes' high-performance success tends to have positive emotional characters and traits, while athletes with less successful performance levels tend to have reasonably high levels of self-control, extraversion, and aggression. So the conclusion provides evidence that psychological and emotional factors have a relationship with an athlete's success.

Besides, it is in line with the research results by Nayaga \& Kusuma [35], proving that five aspects of sleep quality (sleep time, nutrition, exercise, psychological conditions, and environment) it is sufficient to influence the sleep habits of athletes. The five aspects that play an essential role in the psychological aspect have a high percentage of an essential role in influencing athletes' sleep habits to the maximum. The influence of good sleep behavior affects the improvement of sleep quality for athletes. Therefore, it can be concluded that the results of the study prove that recovery can be made with good sleep habits that can improve workability in sports, such as performance in athletes.

Despite the results obtained from such research, the athletes are in their best condition when they are training also competing. It because of habitual factors from athletes that went for a long time and continuously. Even though they do not follow the coach's recommendations according to the theory stated by Samuels and Alexander, they do not force these standards because it is proven not to have different effects. Because besides that, it has shown promising results on the sleep quality of athletes. Given the importance of adequate sleep to reduce the risk of mood-enhancing disorders, prevalent sleep deprivation, and the inability to enforce regulations [36]. The study results are in line with research that is being carried out. Even though athletes do not sleep according to the sport's standards, they could give their best performance while still paying attention to the quantity and quality of sleep 
because of the quantity and quality of sleep. They are reported to be the best psychological and physiological recovery strategies available for elite athletes [21].

As additional information, there are limitations to this study, namely, the instruments used are not on a large scale. Such as sleep quality questionnaires and interview questions to determine sleep quantity do not use a measurement tool. So it is hoped that the weaknesses in this study can be used as a basis for further research that is better at using more valid instruments on a broad scale.

\section{Conclusion}

Based on the results of the data, it can be concluded that there was no significant difference between the total quantity of sleep, the quantity of sleep at night, the number of naps outside the Puslatda and Pelatnas (Clubs), Puslatda, and Pelatnas. There is no significant difference between sleep quality outside the Puslatda and Pelatnas (Clubs), Puslatda and Pelatnas.

It is hoped that with the results like the above, the coaches will pay more attention to the importance (always maintaining the quantity and quality of sleep for the athletes) by regularly sleeping at the recommended nighttime and naps. If they cannot sleep according to international standards, athletes will continue to maintain and remind the maximum quantity and quality of sleep without depressing their mood/psychological state to harm morale/performance both while training or competing.

Acknowledgments. The author would like to thank the Faculty of Sport Science, Universitas Negeri Surabaya who has helped in providing funds for the publication of this scientific article so that the article can be completed smoothly.

\section{References}

[1] Fahmi H, Ashadi. Perdandingan Sport Massage dan Hydrotherapy Cold Water Terhadap Physiological Recovery. JUARA J Olahraga. 2019;4(2):196-207.

[2] Amin N, Lestari YNA. Hubungan Status Gizi, Tingkat Kecukupan Energi dan Zat Gizi dengan Kecepatan pada Atlet Hockey Kota Surabaya. Sport Nutr. 2019;1(1):19-26.

[3] Febrianto DS, Ashadi K. Profil Strategi Pemulihan Secara Fisiologi Atlet Sepakbola Psbi Blitar Senior. J Prestasi Olahraga. 2017;1-10

[4] Abdillah GD, Ashadi K.. Pemahaman pelatih sekolah sepakbola se kota Madiun tentang physiological recovery. J Prestasi Olahraga. 2018;3(1):1-8.

[5] Tanner RK, Gore CJ. Physiological tests for Elite Athletes 2nd Edition. Australian Institute of Sport. Publisher: Human Kinetics. 2013.

[6] Walsh JA, Sanders D, Hamilton DL, Walshe I. Sleep Profiles of Elite Swimmers During Different Training Phases. J Strength Cond Res. 2019;33(3):811-818.

[7] Suwarna AH, Widiyanto. Perbedaan Pola Tidur Antara Kelompok Terlatih Dan Tidak Terlatih. Medikora. 2016;15(1):85-95.

[8] Nedelec M, Aloulou A, Duforez F, Meyer T, Dupont G. The Variability of Sleep Among Elite Athletes. Sport Med. 2018;4(1):1-13.

[9] Qolbi APG, Ashadi K. Perbandingan Pengetahuan Tentang Kesadaran Hidrasi Pada Ukm Bolavoli Putri Dan Ukm Floorball Putri Universitas Negeri Surabaya. J Prestasi Olahraga. 2017;1-7.

[10] Efendi H. Peranan Psikologi Olahraga Dalam Meningkatkan Prestasi Atlet. Nusant (Jurnal Ilmu Pengetah Sos. 2016;1(1):22-30. 
[11] Afriani AE, Margawati A, Dieny FF. Tingkat Stres, Durasi dan Kualitas Tidur, Serta Sindrom Makan Malam Pada Mahasiswi Obesitas Dan Non Obesitas Fakultas Kedokteran. Sport Nutr J. 2019;1(2):63-72.

[12] Samuels C, Alexander B. HUMAN PERFORMANCE A Comprehensive Strategy for. Canadian Sport for Life. 2019;1-20.

[13] Madeira A, Wiyono J, Ariani NL. Hubungan Gangguan Pola Tidur dengan Hipertensi pada Lansia. Nurs News (Meriden). 2019;4(1):29-39.

[14] Lo HM, Leung joyce HY, Chau gavin KY, Lam MH, Lee ka Y, Ho A. Factors Affecting Sleep Quality among Adolescent Athletes. Sport Nutr Ther. 2017;02(02):1-6.

[15] Putra NYP, Tania M, Iklima N, Maulana DL. Perancangan Infografis Tentang Dampak Kebiasaan Begadang Terhadap Pola Tidur Sehat Bagi Remaja. J Sketsa. 2017;4(2):53-60.

[16] Egi E, Prastiwi S, Putri RM. Hubungan Gangguan Tidur dengan Tingkat Kesegaran Jasmani Remaja Putri di SMK Kertha Wisata Kelurahan Tlogomas Kecamatan Lowokwaru Malang. Nurs News (Meriden). 2017;2(1):292-303.

[17] Sugiyono. Metode Penelitian Kuantitatif. Bandung: Alfabeta; 2018. 226 p.

[18] Sugiyono. Metode Penelitian Pendidikan Pendekatan Kuantitatif, Kualitatif, dan R\&D. Bandung: Alfabeta; 2013. 134 p.

[19] Maksum A. Statistik dalam Olahraga. Surabaya: UNESA University Press; 2018. 65 p.

[20] Ghozali I. Aplikasi Analisis Multivariate dengan Program SPSS. Semarang: Badan Penerbit Universitas Diponegoro; 2011. 75 p.

[21] O'Donnell S, Driller MW. Sleep-hygiene Education improves Sleep Indices in Elite Female Athletes. Int J Exerc Sci. 2017;10(4):522-530.

[22] Andriana LM, Ashadi K. Perbandingan dua jenis olahraga pada pagi dan malam hari terhadap kualitas tidur. J Sport J Penelit Pembelajaran. 2019;5(1):99-112.

[23] Killer SC, Svendsen IS, Jeukendrup AE, Gleeson M. Evidence of disturbed sleep and mood state in well-trained athletes during short-term intensified training with and without a high carbohydrate nutritional intervention. J Sports Sci. 2015;35(14):1-9.

[24] Palayukan SS. Faktor- Faktor yang Berhubungan dengan Perubahan Kualitas Tidur Mahasiswa Universitas Megarezky Makassar. Nurs Insid Community. 2020;2(2):59-63.

[25] Fenny, Supriatmo. Hubungan Kualitas dan Kuantitas Tidur dengan Prestasi Belajar pada Mahasiswa Fakultas Kedokteran. J Pendidik Kedokt Indones. 2016;5(3):140-147.

[26] Milewski MD, Skaggs DL, Bishop GA, Pace JL, Ibrahim DA, Wren TAL, et al. Chronic lack of sleep is associated with increased sports injuries in adolescent athletes. J Pediatr Orthop. 2014;34(2):129-133.

[27] Biggins M, Cahalan R, Comyns T, Purtill H, O’Sullivan K. Poor sleep is related to lower general health, increased stress and increased confusion in elite Gaelic athletes. Phys Sportsmed. 2018;46(1):14-20.

[28] Roberts SSH, Teo WP, Warmington SA. Effects of training and competition on the sleep of elite athletes: A systematic review and meta-analysis. Br J Sports Med. 2019;53(8):1-11.

[29] Ji X, Saylor J, Liu J. The interactive effect of habitual midday napping and nighttime sleep duration on impaired fasting glucose risk in healthy adolescents. Sleep Med. 2019;64:77-84.

[30] Rosen P von, Kottorp A, Frohm A, Friden C. Too little sleep and an unhealthy diet could increase the risk of sustaining a new injury in adolescent elite athletes. Scand J Med Sci Sport. 2016;1-8.

[31] Andrade A, Bevilacqua GG, Coimbra DR, Pereira FS, Brandt R. Sleep quality, mood and performance: A study of elite Brazilian volleyball athletes. J Sport Sci Med. 2016;15(4):601-605.

[32] Saputra JJ, Candrawati E, Ahmad ZS. Hubungan Kualitas Tidur Terhadap Kejadian Kram Pada Atlet Futsal. Nurs News (Meriden). 2019;4(1):209-218.

[33] Widhawati R, Maryadi SA, Yulistani A. Hubungan kuantitas tidur dengan konsentrasi belajar remaja di pondok pesantren madinatunnajah tangerang selatan. J Kesehat STIKes IMC Bintaro. 2020;3(2):105-111.

[34] Li B, Ding C, Fan F, Shi H, Guo L, Yang F. Associations Between Psychological Profiles and Performance Success Among Professional Taekwondo Athletes in China: A Multidimensional Scaling Profile Analysis. Front Psychol. 2020;11(822):1-10. 
[35] Nayaga S, Kusuma DA. Analisis Kebiasaan Tidur Pada Fase Latihan Atlet Bola Basket. J Prestasi Olahraga. 2020;3(4).

[36] Booth SA, Carskadon MA, Young R, Short MA. Sleep Duration and Mood in Adolescents: An Experimental Study. Sleep. 2020;1-10. 